\title{
Metaphors of the Students in the Department of History Regarding the Concept of "Value"*
}

\author{
Sezai Oztas \\ Correspondence: Sezai Oztas, Department of History School of Management, Faculty Of Arts And Science, Kirklareli \\ University, Kirklareli, Kayali Campus, Turkey.
}

Received: September 6, 2019

doi:10.11114/jets.v7i10S.4507
Accepted: October 10, $2019 \quad$ Online Published: October 21, 2019

URL: https://doi.org/10.11114/jets.v7i10S.4507

\begin{abstract}
History course curricula provide students with values along with knowledge and skills. The aim of this study is to determine the metaphors related to the concept of value that the students of the history departments have. The study group of the research consists of 75 senior students (from both "day time education" and "evening education") who continue their education in the Department of History of Kirklareli University Faculty of Arts and Sciences in the fall semester of 2018-2019 academic year. In order to collect data, participants were asked to complete the forms which included the sentence "Values are like.......... because.......". The metaphors proposed by the students were categorized in terms of their common characteristics. Phenomenological design, one of the qualitative research methods, was used in this study. The obtained data were analyzed with content analysis method. Additionally, a quantitative data analysis was performed via IBM SPSS Statistics 20 program as well. Descriptive statistics of the collected data were presented in detail. Moreover, it was analyzed whether there is an association between "the main categories of value metaphors given as samples" and the following variables: "Gender", "Education Type", "Mother's Educational Status", "Father's Educational Status", "Type of High School Student Graduated from", "Settlement Unit Where Most of Childhood was Spent", "Perception of Socioeconomic Status", "Number of Siblings", "Hometown (as region)", "Family Type" and "Relationship Status of the Parents". As a result of the Chi-Square Independence Test, it turned out that there was no association between these variables and "the main categories of value metaphors given as examples" (p>0.05).
\end{abstract}

Keywords: the department of history, value, metaphor

\section{Introduction}

The values undergo degeneration at the present time in which a rapid development and change is experienced. Such problems as murder, theft, intolerance, suicide, drug use, corruption, etc. are spiking up and individuals and societies are negatively affected by these situations. Inadequate acquisition of values and inability to internalize them can be considered among the prime reasons for such problems.

Values have an important place in human life. As a result, several researches on values have been done and several books have been written. Despite the fact that several studies have been done and several books have been written regarding values, it is seen that there are different definitions in the literature about the concept of value. Turkish Language Association describes the value in the Turkish Dictionary as "the abstract measure to determine the importance of something; the return or worth of something; the thing that appears in the connection of person as an entity who wants and needs with the object" (Turkish Language Association, 1998: 345). Value is a permanent belief (Rokeach, 1973: 7); the belief whether something is desirable or undesirable (Gungor, 1993: 18); a totality of beliefs that possess the characteristics that make human beings human and contain the basic features that differentiate them from other living things (Ulusoy \& Dilmac, 2016: 16); regardless of the individual's own interests, the beliefs and intuitions determined by the right, wrong and flawless situation to be reached (TUBA, 2011: 280).

Values emerge as criteria in individual's thoughts, attitudes, behaviors and works and constitute an inseparable element of social integrity. In a society's life, everything is perceived according to values and compared with others. Individuals

\footnotetext{
* This study is the revised version of the oral presentation presented at the 3rd International Congress of Eurasian Social Sciences held in Bodrum/Mugla between 18 and 21 April 2019.
} 
generally adopt the values of the group, society and culture in which they live, and use them as criteria for their reasoning and choices. Thus, they have the opportunity to reach general judgments such as better, more accurate, more appropriate, more beautiful, more important and more fair. Individual attitudes and behaviors are substantially under the influence of moral and religious values and the values that customs and traditions contain. However, these values are embodied within norms and become active through norms (Dilmac et al. 2008: 71).

As a result of immaturity in terms of values, people might take unfavourable actions not only against their environment but also against themselves and other people. There exist people who are intolerate of others or people who even exert physical oppression and violence against them once they have the opportunity simply these other people think differently and have different beliefs (Doganay, 2006: 257). The need for the full acquisition of values for students is increasing day by day. Within these context, acquisition of values in educational institutions is of capital importance.

Besides cognitive field education, students receive value education in educational institutions. Value education aims to reinforce the transfer of values in education through the curriculum and the moral atmosphere in schools (Veugelers, 2000: 37). Teachers have highly crucial duties and responsibilities in getting students to acquire values in educational institutions.

History courses play an important role in the acquisition of values. History course curricula provide students with values along with knowledge and skills. Among the target values to teach in history courses through the curriculum are justice, friendship, honesty, self-control, patience, respect, love, responsibility, patriotism, altruism, etc. Getting students to acquire these values is of utmost importance for the peace of individuals and the future of society.

From this perspective, it is prominent to determine the perceptions of the students who continue their university education in history departments, and who are in the process of value acquisition, and who are likely to become history teachers in the future. One of the significant means in determining these perceptions is the metaphors developed by individuals.

It is seen that the concept of metaphor is defined in different ways in the literature. It can be asserted that the reason for the existence of different definitions stems from the fact that each language and culture tries to make a definition according to itself. The concept of metaphor stems from the Greek "metapherein"; meta meaning "to change" and pherein meaning "to bear." (Levine, 2005: 172). According to Yob (2003), metaphor is a powerful mental tool for an individual to understand and explain a highly abstract, complex or theoretical phenomenon. Perry \& Cooper (2001) described the metaphor as describing something unknown with known things. According to Lakoff \& Johnson (1980: 3), "metaphor is pervasive in everyday life, not just in language but in thought and action".

Use of metaphors, in general, is a way of thinking and seeing that helps our grasp of the world (Morgan, 1998). Shuell (1990: 102) emphasized the power of metaphors by saying "If a picture is worth 1000 words, a metaphor is worth 1000 pictures! For a picture provides only a static image while a metaphor provides a conceptual framework for thinking about something".

Although there are studies to find out what the metaphors of students regarding the value concept are (Aladag \& Kuzgun, 2015; Aydin, 2003; Aydin \& Sulak, 2015; Demir Atalay \& Firat Durdukoca, 2018; Kilcan, 2013; Kilcan \& Akbaba, 2018), there is no study on the metaphors of the students in the history departments of the Faculty of Arts and Sciences.

The aim of this study is to reveal the perceptions of history students about the value concept through metaphors. Within the framework of this general aim, answers to the following questions were sought:

1) Through which metaphors do students explain their perceptions of the concept of value?

2) In which categories are these metaphors classified with regards to their common characteristics?

3) Is there an association between "the main categories of value metaphors given as samples" and the following variables: "Gender", "Education Type", "Mother's Educational Status", "Father's Educational Status", "Type of High School Student Graduated from", "Settlement Unit Where Most of Childhood was Spent", "Perception of Socioeconomic Status", "Number of Siblings", "Hometown (as region)", "Family Type" and "Relationship Status of the Parents"?

\section{Method}

\subsection{Research Design}

Phenomenological design, one of the qualitative research methods, was used in this study. Phenomenological design focuses on cases that we are aware of but we do not have in-depth and detailed understanding of. Certain phenomena can be encountered in the world we live in, in various forms such as events, experiences, perceptions, orientations, concepts and situations. Phenomenology creates an appropriate research base for studies aiming to investigate cases that 
are not completely unfamiliar but at the same time we cannot fully understand (Yildirim \& Simsek, 2008). The data collected were analyzed through content analysis technique. In this context, after determining the value metaphor categories and value metaphor main categories that the students gave as an example through their responses, the number of participants (frequency) and their ratio (percentage) which constitute these categories were calculated. Quantitative data analysis was also performed with IBM SPSS Statistics 20 program. Descriptive statistics of the collected data are given in detail. Furthermore, it was analyzed whether there is an association between "the main categories of value metaphors given as examples" and the following variables: "Gender", "Education Type", "Mother's Educational Status", "Father's Educational Status", "Type of High School Student Graduated from", "Settlement Unit Where Most of Childhood was Spent", "Perception of Socioeconomic Status", "Number of Siblings", "Hometown (as region)", "Family Type" and "Relationship Status of the Parents".

\subsection{Study Group}

The study group of the research consists of 75 senior students (from both daytime and evening classes) who continue their education in the Department of History of Kirklareli University Faculty of Arts and Sciences in the fall semester of 2018-2019 academic year. The frequency and percentage distributions of the students participating in the study according to gender are shown in Table 1.

Table 1. The Frequency and Percentage Distribution According to the Students' Gender

\begin{tabular}{lcc}
\hline Gender & Frequency $(\mathrm{n})$ & Percent $(\%)$ \\
\hline Female & 39 & 52.0 \\
Male & 36 & 48.0 \\
\hline Total & 75 & 100.0
\end{tabular}

Of the participants, 39 were female and 36 were male. Female students constitute $52 \%$ and male students constitute $48 \%$ of these students (Table 1).

\subsection{Data Collection Tools}

First of all, the concept of metaphor is explained through examples in order to reveal the metaphors that the students of the history department have regarding the concept "of value". Thereafter the data of the research were obtained by completing the forms in which the following sentence is written "Values are like.......... because.......". Students spent 25-30 minutes to fill in the forms.

\subsection{Data Analysis}

In this study, "content analysis" technique was used to evaluate the data obtained. The main purpose of content analysis is to reach the concepts and relations that can explain the collected data. The data summarized and interpreted in the descriptive analysis are tested with a deeper process in the content analysis and the concepts and themes that can not be noticed by the descriptive approach can be discovered by way of this analysis. We try to identify data through content analysis and reveal the facts that may be hidden in the data. The basic process in content analysis is to bring together similar data within the framework of certain concepts and themes and interpret these by arranging them in a way that the reader is able to understand (Yildirim \& Simsek, 2008: 227).

In the analysis and interpretation of the metaphors developed by the students, former studies carried out by Aydin (2010), Candan \& Aydin (2016), Saban (2004), Saban (2009), Saban, Kocbeker \& Saban (2006) were followed. The analysis and interpretation of the metaphors took place in five stages. These stages are: (1) Naming Phase, (2) Classification (Elimination and Purification) Phase, (3) Category Development Phase, (4) Validation and Reliability Phase, and (5) Data Transfer to Computer Environment Phase.

\subsubsection{Naming Phase}

A temporary list of the metaphors produced by the students participating in the research is made in alphabetical order. Then, it was examined whether the metaphors were written properly. The metaphors written by the students in the forms they presented were coded. Papers that did not include any metaphors were marked.

\subsubsection{Classification (Elimination and Purification) Stage}

At this stage, the metaphors written by the students in the forms were read again and revised. Each metaphor was analyzed in terms of its subject, source and the relationship between the subject and the source. Not all students succeeded in producing valid metaphors. Metaphors defined as "Weak metaphor" such as forms that do not contain any metaphor sources, invalid forms and metaphors belonging to more than one category, unreasonable or not associated with the concept of value were excluded from the scope of the research. 


\subsubsection{Category Development Phase}

At this stage, the metaphors produced by the participants were examined in terms of their common characteristics related to the concept of value. Considering how each metaphor conceptualizes the phenomenon of "value from the list of metaphors, 7 different categories were formed by associating them with a specific theme according to the perspective of each metaphor. Afterwards these 7 categories were grouped into 2 main categories.

\subsubsection{Validity and Reliability Stage}

Validity and reliability are the two most crucial criteria used to ensure the credibility of the results of a scientific research (Yildirim \& Simsek, 2008). The data analysis process was explained elaborately to ensure the validity of the research. In order to ensure the reliability of the research, 2 expert faculty members were consulted on the metaphors and the categories formed. Metaphors which were thought to belong to different categories were discussed over and the categories were finalized. Miles \& Huberman's (1994) formula (Reliability = Consensus / Consensus + Dissidence) was used to calculate the reliability coefficient. As a result of this calculation, it is seen that a consensus of $95 \%$ was achieved.

\subsubsection{Data Transfer to Computer Phase}

The data was transferred to computer for quantitative analysis. Quantitative analysis of data was carried out with $95 \%$ reliability level on SPSS 20 Windows (Statistical Packages for Social Sciences) program. The details of the quantitative data analysis presented in the Results section are as follows:

- Frequency Analysis: Frequency and ratio information of "Gender", "Education Type", "Mother's Educational Status", "Father's Educational Status", "Type of High School Student Graduated from", "Settlement Unit Where Most of Childhood was Spent", "Perception of Socioeconomic Status", "Number of Siblings", "Hometown (as region)", "Family Type" and "Relationship Status of the Parents" were given in tables.

- Hypothesis Testing: The hypotheses of the research were examined via "Chi-Square Independence Test. According to this; it was analyzed whether the value metaphors (categorically) produced by the participants of the survey associate with each of the following variables respectively: "Gender", "Education Type", "Mother's Educational Status", "Father's Educational Status", "Type of High School Student Graduated from", "Settlement Unit Where Most of Childhood was Spent", "Perception of Socioeconomic Status", "Number of Siblings", "Hometown (as region)", "Family Type" and "Relationship Status of the Parents".

\section{Results}

In this section, the results of data analysis were given in the tables.

Through which metaphors do students explain their perceptions of the concept of value?

General Findings Related to Students' Metaphors about the Concept of Value

According to the general findings obtained from this study, history students produced 54 valid metaphors related to the concept of value (Table 2). The most preferred metaphors for the concept of value by students were family (f=5) and mother $(\mathrm{f}=3)$. Besides these, gold $(\mathrm{f}=2)$, glower $(\mathrm{f}=2)$, emotion $(\mathrm{f}=2)$, teacher $(\mathrm{f}=2)$, respect $(\mathrm{f}=2)$, source of love $(\mathrm{f}=2)$ and water $(\mathrm{f}=2)$ metaphors were preferred more than once. The metaphors developed by the history students participating in the survey were listed in alphabetical order and each metaphor and the number (frequencies) of students representing each metaphor are given below (Table 2). 
Table 2. The Metaphors Developed by the History Students Related to the Concept of "Value" and the Number of Students Representing Them (f)

\begin{tabular}{|c|c|c|c|c|c|}
\hline No & Metaphors & Frequency (f) & No & Metaphors & Frequency (f) \\
\hline 1 & Family & 5 & 28 & Holy & 1 \\
\hline 2 & Gold & 2 & 29 & Polar Star & 1 \\
\hline 3 & Mother & 3 & 30 & Culture & 1 \\
\hline 4 & Seasoning & 1 & 31 & Cashier in the Market & 1 \\
\hline 5 & Space & 1 & 32 & The Pursuit of Happiness & 1 \\
\hline 6 & Flower & 2 & 33 & Pleasing & 1 \\
\hline 7 & Farming & 1 & 34 & Music & 1 \\
\hline 8 & Ordeal & 1 & 35 & School & 1 \\
\hline 9 & Mountain & 1 & 36 & Teacher & 2 \\
\hline 10 & Language & 1 & 37 & Individuals Cared for & 1 \\
\hline 11 & Emotion & 2 & 38 & Police & 1 \\
\hline 12 & Sun & 1 & 39 & Respect & 2 \\
\hline 13 & Memory & 1 & 40 & Those I love & 1 \\
\hline 14 & Life & 1 & 41 & Love & 1 \\
\hline 15 & Meaning of Life & 1 & 42 & Source of Love & 2 \\
\hline 16 & Vital Needs & 1 & 43 & Water & 2 \\
\hline 17 & Treasure & 1 & 44 & Beloved One & 2 \\
\hline 18 & Peace & 1 & 45 & God & 1 \\
\hline 19 & Light & 1 & 46 & History & 1 \\
\hline 20 & Human & 1 & 47 & Seed & 1 \\
\hline 21 & Human Perspective on Environment & 1 & 48 & Pen & 2 \\
\hline 22 & Islam & 1 & 49 & Existence & 1 \\
\hline 23 & Worker & 1 & 50 & Rain & 1 \\
\hline 24 & Pencil & 1 & 51 & Purpose of Life & 1 \\
\hline 25 & Butterfly & 1 & 52 & Star & 2 \\
\hline 26 & Clothing & 1 & 53 & Being Honourable & 1 \\
\hline 27 & Precious Items & 1 & 54 & Chain & 2 \\
\hline
\end{tabular}

In which categories are these metaphors classified in terms of their common characteristics?

Categories Formed by the Metaphors of History Students Related to the Concept of Value ${ }^{l}$

After analysing the metaphors of history students about the concept of value, these metaphors were evaluated in 7 categories. While categorizing these metaphors, not just the word meaning of the metaphor, but the rationale of the developed metaphor was taken into consideration and the explanations made after "because..." were taken into consideration. The categories created based on the metaphors of the participants are: "Value as a concept that includes holiness", "Value as an identifier", "Value as an ensurer of social sustainability", "Value as a guide", "Value as a provider of life energy", "Value as a social integrator", "Value as emotions that must be kept alive". The metaphors of history students regarding the concept of value and the main categories of metaphors are shown below (Table 3).

\footnotetext{
${ }^{1}$ Seven categories were determined and these seven categories were grouped under two main categories.
} 
Table 3. Metaphor Categories of History Students Related to the Concept of Value

\begin{tabular}{|c|c|c|c|c|c|}
\hline $\begin{array}{l}\text { Main } \\
\text { Category of } \\
\text { Metaphor }\end{array}$ & $\begin{array}{l}\text { Category of } \\
\text { Metaphor }\end{array}$ & Metaphor & $\begin{array}{l}\text { Number } \\
\text { of } \\
\text { Metaphor }\end{array}$ & $\begin{array}{l}\text { Metaphor } \\
\text { Frequency* }\end{array}$ & $\begin{array}{l}\text { Metaphor } \\
\text { Percentage }\end{array}$ \\
\hline \multirow{4}{*}{ 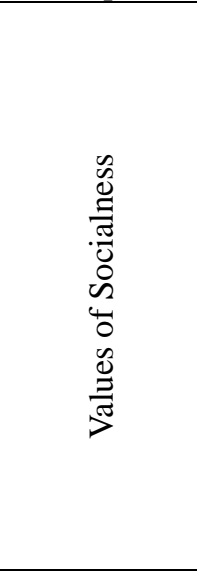 } & $\begin{array}{l}\text { Value as a } \\
\text { concept that } \\
\text { includes holiness }\end{array}$ & $\begin{array}{l}\text { Beloved One, Mother (3), Worker, God, } \\
\text { Precious Items, Family, Water, Gold, } \\
\text { Treasure }\end{array}$ & 9 & 11 & $15 \%$ \\
\hline & $\begin{array}{l}\text { Value as a social } \\
\text { integrator }\end{array}$ & $\begin{array}{l}\text { Chain, Ordeal, Cashier in the Market, } \\
\text { Human Perspective on Environment, } \\
\text { Rain, Peace, Being Honourable, Family } \\
\text { (2), Life, Language }\end{array}$ & 10 & 11 & $15 \%$ \\
\hline & $\begin{array}{l}\text { Value as an } \\
\text { ensurer of social } \\
\text { sustainability }\end{array}$ & $\begin{array}{l}\text { Chain, Pen (2), Mountain, Police, } \\
\text { Memory, Space }\end{array}$ & 6 & 7 & $10 \%$ \\
\hline & Value as a guide & $\begin{array}{l}\text { Star (2), Polar Star, Sun, Teacher (2), } \\
\text { Light }\end{array}$ & 5 & 7 & $10 \%$ \\
\hline \multirow{3}{*}{ 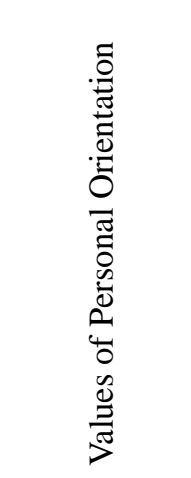 } & $\begin{array}{llr}\text { Value } & \text { as } & \text { a } \\
\text { provider } & \text { of } & \text { life } \\
\text { energy } & & \end{array}$ & $\begin{array}{l}\text { Purpose of Life, Love, Meaning of Life, } \\
\text { Source of Love (2), the Pursuit of } \\
\text { Happiness, Pleasing, Music, Gold, } \\
\text { Emotion (2), Farming, Family, } \\
\text { Individuals Cared for }\end{array}$ & 12 & 14 & $20 \%$ \\
\hline & $\begin{array}{l}\text { Value as an } \\
\text { identifier }\end{array}$ & $\begin{array}{l}\text { Vital Needs, Clothing, School, Pencil, } \\
\text { Holy, Seasoning, Existence, Islam, } \\
\text { Culture, Butterfly, History }\end{array}$ & 11 & 11 & $15 \%$ \\
\hline & $\begin{array}{l}\text { Value as emotions } \\
\text { that must be kept } \\
\text { alive }\end{array}$ & $\begin{array}{l}\text { Family, Flower (2), Human, Society, } \\
\text { Respect (2), Those I love, Water, Beloved } \\
\text { One }\end{array}$ & 8 & 10 & $14 \%$ \\
\hline Total & & & 61 & 71 & $100 \%$ \\
\hline
\end{tabular}

* Number of Students

When Table 3 is examined, it is realized that the students consider the value as "Value as a provider of life energy" the most (n: 14, 20\%). This is followed by "Value as a concept that includes holiness "(n: 11, 15\%), "Value as a social integrator" (n: 11, 15\%), "Value as an identifier" (n: 11, 15\%), "Value as emotions that must be kept alive" (n: 10, 14\%), "Value as a guide" (n: 7, 10\%), "Value as an ensurer of social sustainability" (n: 7, 10\%) respectively.

Category 1: Value as a concept that includes holiness

This category seems to consist of 9 metaphors and 11 students (15\%). Some sample student statements in this category where loftiness and sanctity of value are emphasized are given below.

"It is like a mother because it gives unrequited love when the person needs it. It is always there when you need it, and it solves problems before you know it.

"It is like a mother because it carries the love of the mother. It means it is being with a person for the rest of his/her life and in his/her mind."

Category 2: Value as a social integrator

This category seems to consist of 10 metaphors and 11 students (15\%). Some sample student statements in this category where social integrative feature of the concept of value is emphasized are given below.

"It is like a language because it holds a society together. It gives the society unique characteristics. Every society has its own characteristics. It is impossible to speak of a nation without the values that make up this nation."

"It's like rain because it surrounds and cools you down and when you don't expect it."

Category 3: Value as an ensurer of social sustainability

This category seems to consist of 6 metaphors and 7 students (10\%). Some sample student statements in this category where social sustainability of the concept of value is emphasized are given below.

"It is like the police force because it has a protective power. It has the ability to help its people and provide security for 
them. It prevents those who cause unrest. It acts as the iron fist of the state. It is the security unit that strives to protect the indivisible unity of the country. It is the core unit of the state's justice mechanism. From this perspective, the police force is like values in some way."

"It is like a mountain because it is the one who continues itself from the past to the present within certain rules. It is like a mountain because it is the one who does not fall down and who has the ability to stand up."

Category 4: Value as a guide

This category seems to consist of 5 metaphors and 7 students (10\%). Some sample student statements in this category where guiding characteristic of the concept of value is emphasized are given below.

"It is like light because it guides mankind, directs them to the good. Like light, value protects man from evil and darkness. It guides mankind. A man's value is like his/her light.",

"It is like the Polar Star because your values guide you the way the polar star guides you when you are in the dark."

"It is like the sun because it sheds light on societies and guides them to the right path to complete their personality development."

Category 5: Value as a provider of life energy

This category seems to consist of 12 metaphors and 14 students $(20 \%)$. "Value as a provider of life energy" is the category most favored by students and has the highest number of students. Below are some student statements that make up this category.

"It is like farming because it makes you earn to the extent you care for it. So it cannot be neglected and requires labor. Otherwise it will cause you to lose."

"It's like the meaning of life because if we don't have values, we lose the motivation for life."

Category 6: Value as an identifier

This category seems to consist of 11 metaphors and 11 students (15\%). Some sample student statements in this category where identifying characteristic of the value concept is emphasized are given below.

"It is like a clothing because it wraps you depending on the place and time. It may comfort you, or may keep you warm or cool when needed. Is that not like what clothes do? You choose clothes according to the place, season, weather or sometimes according to the region you live in. The value is shaped in parallel to the region we live in.

"It's like a school because it always teaches something."

Category 7: Value as emotions that must be kept alive

This category seems to consist of 8 metaphors and 10 students (14\%). Below are some sample student statements in this category where emphasis is given to the emotions that must be experienced.

"It's like a flower because it blossoms and blooms as long as you water and look after the flower. Value is like a flower, in that it is attached to importance and care. Values are lost just like flowers lose strength and perish if they are not watered and cared about adequately.

"It is like the beloved one because it is unforgettable and can not be ignored as well. You can not simply forget and ignore your beloved one and national values even if you want it. The longer you keep away, the more you miss and love. You can not do without it."

Analysis of Frequency

Table 4. Student Distribution According to the Education Type

\begin{tabular}{lcc}
\hline Education Type & Frequency $(\mathrm{n})$ & Percent $(\%)$ \\
\hline Day Classes & 42 & 56.8 \\
Evening Classes & 32 & 43.2 \\
\hline Total & 74 & 100.0 \\
\hline
\end{tabular}

$56.8 \%$ of the respondents were day time students and $43.2 \%$ were evening students (Table 4 ). 
Table 5. Distribution of Parents' Educational Status

\begin{tabular}{lcccc}
\hline & \multicolumn{2}{c}{ Mother } & \multicolumn{2}{c}{ Father } \\
Educational Status & Frequency (n) & Percent $(\%)$ & Frequency (n) & Percent $(\%)$ \\
\hline Not literate & 9 & 12.0 & 2 & 2.7 \\
Literate (School Unfinished) & 6 & 8.0 & 4 & 5.3 \\
Primary School Graduate & 34 & 45.3 & 36 & 48.0 \\
Secondary School Graduate & 14 & 18.7 & 19 & 25.3 \\
High School Graduate & 8 & 10.7 & 11 & 14.7 \\
Associate Degree Holder & 1 & 1.3 & 0 & 0 \\
Bachelor's Degree Holder & 3 & 4.0 & 3 & 4.0 \\
\hline Total & 75 & 100.0 & 75 & 100.0
\end{tabular}

The distribution of the educational status of the parents of the respondents is given in the table above (Table 5).

Table 6. Distribution of the Type of High School Respondents Graduated from

\begin{tabular}{lcc}
\hline Type of High School & Frequency $(\mathrm{n})$ & Percent $(\%)$ \\
\hline Anatolian High School & 28 & 37.3 \\
Anatolian Vocational High & 3 & 4.0 \\
Industrial Vocational High & 6 & 8.0 \\
Vocational High School & 4 & 5.3 \\
Religious Vocational High & 7 & 9.3 \\
General High School & 21 & 28.0 \\
Technical High School & 2 & 2.7 \\
Others & 4 & 5.3 \\
\hline Total & 75 & 100.0
\end{tabular}

$37.3 \%$ of the respondents were Anatolian High School, 4\% Anatolian Vocational High School, $8 \%$ Industrial Vocational High School, 5.3\% Vocational High School, 9.3\% Religious Vocational High School, 28\% General High School, 2.7\% Technical High School graduates and 5.3\% were graduates of other high schools (Table 6).

Table 7. Distribution of Settlement Units Where Childhood was Spent

\begin{tabular}{lcc}
\hline Settlement Unit & Frequency (n) & Percent (\%) \\
\hline Village & 14 & 18.7 \\
District & 18 & 24.0 \\
Province & 43 & 57.3 \\
\hline Total & 75 & 100.0
\end{tabular}

$18.7 \%$ of the respondents spent their childhood in a village, $24 \%$ in a district and $57.3 \%$ in a province (Table 7 ).

Table 8. Distribution of Perceived Socioeconomic Status

\begin{tabular}{lcc}
\hline Socioeconomic Status & Frequency $(\mathrm{n})$ & Percent $(\%)$ \\
\hline Low & 7 & 10.1 \\
Medium & 62 & 89.9 \\
\hline Total & 69 & 100.0
\end{tabular}

$10.1 \%$ of the respondents perceived their socioeconomic status as low and $89.9 \%$ as medium (Table 8). 
Table 9. Distribution of the Number of Siblings

\begin{tabular}{ccc}
\hline $\begin{array}{c}\text { Number of Siblings } \\
\text { (Including Respondent) }\end{array}$ & Frequency $(\mathrm{n})$ & Percent $(\%)$ \\
\hline 1 & 7 & 9.3 \\
2 & 28 & 37.3 \\
3 & 17 & 22.7 \\
4 & 7 & 9.3 \\
5 & 5 & 6.7 \\
6 & 6 & 8.0 \\
7 & 3 & 4.0 \\
8 & 2 & 2.7 \\
\hline Total & 75 & 100.0
\end{tabular}

$9.3 \%$ of the respondents have one sibling, $37.3 \%$ two siblings, $22.7 \%$ three siblings, $9.3 \%$ four siblings, $6.7 \%$ five siblings, $8 \%$ six siblings, $4 \%$ seven siblings and $2.7 \%$ eight siblings (Table 9 ).

Table 10. Distribution of Hometowns (as region)

\begin{tabular}{lcc}
\hline Hometown (as region) & Frequency $(\mathrm{n})$ & Percent $(\%)$ \\
\hline The Marmara Region & 28 & 37.3 \\
The Aegean Region & 2 & 2.7 \\
The Black Sea Region & 18 & 24.0 \\
The Central Anatolia Region & 10 & 13.3 \\
The Mediterranean Region & 1 & 1.3 \\
The Eastern Anatolia Region & 10 & 13.3 \\
The Southeast Anatolia & 4 & 5.3 \\
Region & & \\
Turkmenistan & 2 & 2.7 \\
\hline Total & 75 & 100.0 \\
\hline
\end{tabular}

$37.3 \%$ of respondents were Marmara, 2.7\% Aegean, 24\% Black Sea, 13.3\% Central Anatolian, 1.3\% Mediterranean, 13.3\% Eastern Anatolian, 5.3\% Southeastern Anatolian and 2.7\% Turkmenian origin (Table 10).

Table 11. Distribution of Family Types

\begin{tabular}{lcc}
\hline Family Type & Frequency(n) & Percent $(\%)$ \\
\hline Nuclear Family & 57 & 76.0 \\
Extended Family & 18 & 24.0 \\
\hline Total & 75 & 100.0
\end{tabular}

$76 \%$ of the respondents have a nuclear family and $24 \%$ an extended family (Table 11).

Table 12. Distribution Regarding the Relationship Status of the Parents

\begin{tabular}{lcc}
\hline Are Your Parents Together? & Frequency $(\mathrm{n})$ & Percent $(\%)$ \\
\hline Together & 65 & 86.7 \\
Separate & 5 & 6.7 \\
Other & 5 & 6.7 \\
\hline Total & 75 & 100.0
\end{tabular}

$86.7 \%$ of the respondents' parents are together, $6.7 \%$ of the parents are separate and $6.7 \%$ has stated the relationship status of their parents as other (Table 12).

Is there an association between "the main categories of value metaphors given as samples" sand the following variables: "Gender", "Education Type", "Mother's Educational Status", "Father's Educational Status", "Type of High School Student Graduated from", "Settlement Unit Where Most of Childhood was Spent", "Perception of Socioeconomic Status", "Number of Siblings", "Hometown (as region)”, "Family Type” and "Relationship Status of the Parents?" 
Hipothesis Testing

Table 13. Chi-Square Test of Independence (Gender-Main Category of Value Metaphor) Result Table

\begin{tabular}{|c|c|c|c|c|c|c|}
\hline \multicolumn{7}{|c|}{ MAIN CATEGORY OF VALUE METAPHOR } \\
\hline & & $\mathrm{n}$ & $\begin{array}{l}\text { Values of } \\
\text { Socialness }\end{array}$ & $\begin{array}{c}\text { Values of } \\
\text { Personal } \\
\text { Orientation }\end{array}$ & $\chi^{2}$ & $p$ \\
\hline \multirow{3}{*}{ GENDER } & Female & 37 & 22 & 15 & \multirow{3}{*}{0.157} & \multirow{3}{*}{0,124} \\
\hline & Male & 34 & 14 & 20 & & \\
\hline & Total & 71 & 36 & 35 & & \\
\hline
\end{tabular}

According to the chi-square test of independence, no statistically significant relationship was found between gender and main categories of students' sample value metaphors $\chi_{(1)}^{2}=0.157, p>0.05$ (Table 13).

Table 14. Chi-Square Test of Independence (Mother's Educational Status-Main Category of Value Metaphor) Result Table

\begin{tabular}{|c|c|c|c|c|c|c|}
\hline \multicolumn{7}{|c|}{ MAIN CATEGORY OF VALUE METAPHOR } \\
\hline & & $\mathrm{n}$ & $\begin{array}{l}\text { Values of } \\
\text { Socialness }\end{array}$ & $\begin{array}{l}\text { Values of Personal } \\
\text { Orientation }\end{array}$ & $\chi^{2}$ & $p$ \\
\hline \multirow{4}{*}{$\begin{array}{c}\text { MOTHER'S } \\
\text { EDUCATIONAL STATUS }\end{array}$} & $\begin{array}{l}\text { Graduate of Primary } \\
\text { School or Lower Degree }\end{array}$ & $\begin{array}{l}4 \\
7\end{array}$ & 26 & 21 & \multirow{4}{*}{$\begin{array}{c}1.66 \\
1\end{array}$} & \multirow{4}{*}{0.436} \\
\hline & $\begin{array}{l}\text { Graduate of } \\
\text { Secondary School }\end{array}$ & $\begin{array}{l}1 \\
4\end{array}$ & 5 & 9 & & \\
\hline & $\begin{array}{l}\text { Graduate of High } \\
\text { School or Higher Degree }\end{array}$ & $\begin{array}{l}1 \\
0\end{array}$ & 5 & 5 & & \\
\hline & Total & $\begin{array}{l}7 \\
1\end{array}$ & 36 & 35 & & \\
\hline
\end{tabular}

According to the chi-square test of independence, no statistically significant relationship was found between mother's educational status and main categories of students' sample value metaphors $\left(\chi_{(2)}^{2}=1.61, p>0.05\right)$ (Table 14).

Table 15. Chi-Square Test of Independence (Father's Educational Status-Main Category of Value Metaphor) Result Table

MAIN CATEGORY OF VALUE METAPHOR

\begin{tabular}{|c|c|c|c|c|c|c|}
\hline & & $\mathrm{n}$ & $\begin{array}{l}\text { Values of } \\
\text { Socialness }\end{array}$ & $\begin{array}{l}\text { Values of } \\
\text { Personal } \\
\text { Orientation }\end{array}$ & $\chi^{2}$ & $p$ \\
\hline \multirow{4}{*}{$\begin{array}{c}\text { FATHER'S } \\
\text { EDUCATIONAL } \\
\text { BACKGROUND }\end{array}$} & $\begin{array}{l}\text { Graduate of Primary } \\
\text { School or Lower Degree }\end{array}$ & 42 & 23 & 19 & \multirow{4}{*}{1.059} & \multirow{4}{*}{0.589} \\
\hline & $\begin{array}{l}\text { Graduate of Secondary } \\
\text { School }\end{array}$ & 16 & 8 & 8 & & \\
\hline & $\begin{array}{l}\text { Graduate of High School } \\
\text { or Higher Degree }\end{array}$ & 13 & 5 & 8 & & \\
\hline & Total & 71 & 36 & 35 & & \\
\hline
\end{tabular}

According to the chi-square test of independence, no statistically significant relationship was found between father's educational status and main categories of students' sample value metaphors $\left.\chi_{(2)}^{2}=1.059, p>0.05\right)$ (Table 15). 
Table 16. Chi-Square Test of Independence (High School Type-Main Category of Value Metaphor) Result Table MAIN CATEGORY OF VALUE METAPHOR

\begin{tabular}{clccccc} 
& $\mathrm{n}$ & $\begin{array}{c}\text { Values of } \\
\text { Socialness }\end{array}$ & $\begin{array}{c}\text { Values of Personal } \\
\text { Orientation }\end{array}$ & $\chi^{2}$ & $p$ \\
\hline \multirow{2}{*}{\begin{tabular}{c} 
HIGH \\
SCHOOL \\
\multirow{2}{*}{ TYPE }
\end{tabular}} & Anatolian High School & 27 & 14 & 13 & & \\
& General High School & 19 & 13 & 6 & \multirow{2}{*}{4.563} & 0.102 \\
\cline { 2 - 4 } & Other & 25 & 9 & 16 & &
\end{tabular}

According to the chi-square test of independence, no statistically significant relationship was found between the type of high school from which students graduated and main categories of students' sample value metaphors $\left(\chi_{(2)}^{2}=4.563\right.$, $p>0.05$ ) (Table 16).

Table 17. Chi-Square Test of Independence (Settlement Unit Where Childhood was Spent-Main Category of Value Metaphor) Result Table

\section{MAIN CATEGORY OF VALUE METAPHOR}

\begin{tabular}{|c|c|c|c|c|c|c|}
\hline & & $\mathrm{n}$ & $\begin{array}{l}\text { Values } \\
\text { of } \\
\text { Socialness }\end{array}$ & $\begin{array}{c}\text { Values of } \\
\text { Personal } \\
\text { Orientation }\end{array}$ & $\chi^{2}$ & $p$ \\
\hline \multirow{3}{*}{$\begin{array}{c}\text { SETTLEMENT } \\
\text { UNIT WHERE } \\
\text { CHILDHOOD } \\
\text { WAS SPENT }\end{array}$} & Village & 14 & 4 & 10 & \multirow{4}{*}{3.421} & \multirow{4}{*}{0.181} \\
\hline & District & 18 & 10 & 8 & & \\
\hline & Province & 39 & 22 & 17 & & \\
\hline & Total & 71 & 36 & 35 & & \\
\hline
\end{tabular}

According to the chi-square test of independence, no statistically significant relationship was found between the settlement unit where students' childhood was spent and main categories of students' sample value metaphors $\left(\chi_{(2)}^{2}=3.421, p>0.05\right)$ (Table 17).

Table 18. Chi-Square Test of Independence (Perception of Socioeconomic Status-Main Category of Value Metaphor) Result Table

\section{MAIN CATEGORY OF VALUE METAPHOR}

\begin{tabular}{|c|c|c|c|c|c|}
\hline & & $\mathrm{n}$ & $\begin{array}{l}\text { Values of } \\
\text { Socialness }\end{array}$ & $\begin{array}{c}\text { Values of } \\
\text { Personal } \\
\text { Orientation }\end{array}$ & $p$ \\
\hline \multirow{3}{*}{$\begin{array}{l}\text { HOW WOULD YOU } \\
\text { DESCRIBE YOUR } \\
\text { SCOIOECONOMIC } \\
\text { STATUS? }\end{array}$} & Low & 6 & 2 & 4 & \\
\hline & Medium & 59 & 31 & 28 & 0.427 \\
\hline & Total & 65 & 33 & 32 & \\
\hline
\end{tabular}

According to the chi-square test of independence, no statistically significant relationship was found between the students' perception of socioeconomic status and main categories of students' sample value metaphors $(p<0.05$, Fisher's Exact Test) (Table 18). 
Table 19. Chi-Square Test of Independence (Number of Siblings-Main Category of Value Metaphor) Result Table MAIN CATEGORY OF VALUE METAPHOR

\begin{tabular}{|c|c|c|c|c|c|c|}
\hline & & 11 & $\begin{array}{c}\text { Values of } \\
\text { socialness }\end{array}$ & $\begin{array}{c}\text { Values of Social } \\
\text { Orientation } \\
\end{array}$ & $\chi^{2}$ & $p$ \\
\hline \multirow{4}{*}{$\begin{array}{l}\text { NUMBER OF } \\
\text { SIBLINGS }\end{array}$} & $\begin{array}{lrl}2 & \text { or } & \text { fewer } \\
\text { siblings } & \end{array}$ & 34 & 16 & 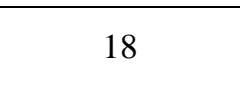 & \multirow{4}{*}{1.477} & \multirow{4}{*}{0.478} \\
\hline & 3 siblings & 14 & 6 & 8 & & \\
\hline & 4 or more siblings & 23 & 14 & 9 & & \\
\hline & Total & 71 & 36 & 35 & & \\
\hline
\end{tabular}

According to the chi-square test of independence, no statistically significant relationship was found between the number of students' siblings and main categories of students' sample value metaphors $\left(\chi_{(2)}^{2}=1.477, p<0.05\right)$ (Table 19).

Table 20. Chi-Square Test of Independence (Hometown-Main Category of Value Metaphor) Result Table

\section{MAIN CATEGORY OF VALUE METAPHOR}

\begin{tabular}{clccccc} 
& & $\mathrm{n}$ & Values of Socialness & Values of Personal Orientation & $\chi^{2}$ & $p$ \\
\hline \multirow{3}{*}{ HOMETOWN } & The Marmara Region & 28 & 14 & 14 & \\
& The Black Sea Region & 16 & 9 & 7 & 0.273 & 0.872 \\
\cline { 2 - 5 } & The Other Regions & 27 & 13 & & \\
\cline { 2 - 5 } & Total & 71 & 36 & 35 &
\end{tabular}

According to the chi-square test of independence, no statistically significant relationship was found between the students' hometown (as region) and main categories of students' sample value metaphors $\left(\chi_{(2)}^{2}=0.273, p>0.05\right)$ (Table 20).

Table 21. Chi-Square Test of Independence (Family Type-Main Category of Value Metaphor) Result Table

\begin{tabular}{cllcccc}
\hline \multicolumn{7}{c}{ MAIN CATEGORY OF VALUE METAPHOR } \\
\hline & \multicolumn{1}{c}{$\mathrm{n}$} & Values of Socialness & Values of Personal Orientation & $\chi^{2}$ & $p$ \\
\hline \multirow{2}{*}{ FAMILY } & Nuclear Family & 37 & 26 & 27 & \\
\multirow{2}{*}{ TYPE } & Extended Family & 18 & 10 & 8 & 0.227 & 0.786 \\
\cline { 2 - 6 } & Total & 71 & 36 & 35 & \\
\hline
\end{tabular}

According to the chi-square test of independence, no statistically significant relationship was found between the students' family type and main categories of students' sample value metaphors $\left(\chi_{(1)}^{2}=0.227, p>0.05\right)$ (Table 21).

Table 22. Chi-Square Test of Independence (Relationship Status of the Parents-Main Category of Value Metaphor) Result Table

$$
\text { MAIN CATEGORY OF VALUE METAPHOR }
$$

\begin{tabular}{clccccc} 
& & $\mathrm{n}$ & $\begin{array}{c}\text { Values of } \\
\text { Socialness }\end{array}$ & $\begin{array}{c}\text { Values of Personal } \\
\text { Orientation }\end{array}$ & $\chi^{2}$ & $p$ \\
\hline ARE YOUR & Together & 61 & 30 & 31 & & \\
PARENTS TOGETHER? & Other Cases & 10 & 6 & 4 & 0.402 & 0.735 \\
\cline { 1 - 5 } & Total & 71 & 36 & 35 & &
\end{tabular}

According to the chi-square test of independence, no statistically significant relationship was found between relationship status of the students' parents and main categories of students' sample value metaphors $\left(\chi_{(I)}^{2}=0.402\right.$, $p>0.05$ ) (Table 22). 


\section{Discussion}

This research aims to reveal the metaphors that history students have related to the concept of value, to group these metaphors under certain conceptual categories and to determine whether there is association between the following variables: "Gender", "Education Type", "Mother's Educational Status", "Father's Education Status", "Type of High School Student Graduated from", "Settlement Unit Where Most of Childhood was Spent", "Perception of Socioeconomic Status", "Number of Siblings", "Hometown (as region)", "Family Type" and "Relationship Status of the Parents", and main categories of students' sample value metaphors. The findings of this research point out the issues below:

It was determined that history students came up with 54 different metaphors for the concept of value. The most preferred metaphors for the concept of value by students were family $(\mathrm{f}=5)$ and mother $(\mathrm{f}=3)$. After analysing the metaphors of history students about the concept of value, these metaphors were evaluated in 7 categories. While categorizing these metaphors, not just the word meaning of the metaphor, but the rationale of the developed metaphor was taken into consideration and the explanations made after "because..." were considered in this process. The categories created based on the metaphors of the participants are: "Value as a concept that includes holiness", "Value as an identifier", "Value as an ensurer of social sustainability", "Value as a guide", "Value as a provider of life energy", Value as a social integrator", "Value as emotions that must be kept alive". History students came up with the most metaphors in the category "Value as a provider of life energy" (12 metaphors) and the least metaphors in the category "Value as a guide" (5 metaphors). The metaphors uttered by the history students was found to have positive meaning in general.

When the relevant literature is examined, it is seen that similar results have been reached in the metaphor studies regarding the concept of "value". In the research conducted by Aladag \& Kuzgun (2015) in order to determine the metaphor perceptions of the prospective primary education teachers, 330 different views on values were obtained from the opinions of these prospective primary education teachers. According to the results of the study, it was found that the participants produced a total of 107 valid metaphors for the concept of value. In the research conducted by Aydin \& Sulak (2015) to determine metaphor perceptions of the prospective primary education teachers about the concept of value, the prospective primary education teachers came up with 79 different metaphors. These metaphors were classified under 5 different categories: value as a necessity (27), value as uniting and shaping (21), value as a variable (17), value as a source of happiness (10) and value as a guide (4). In the study conducted by Demir Atalay \& Firat Durdukoca (2018) to determine metaphorical perceptions of prospective teachers regarding national, spiritual and universal value concepts, 154 out of 182 prospective teachers having participated in the study came up with 71 valid metaphors regarding the concept of national value, 125 of them came up with 59 metaphors regarding spiritual value and 140 of them came up with 67 metaphors regarding universal value. An important conclusion obtained when the relevant literature is examined and obtained from the result of this research is that it is not possible to fully explain the concept of "value" with only one metaphor.

In this study, quantitative data analysis was also performed with IBM SPSS Statistics 20 program. It was researched whether there is an association between the following variables: "Gender", "Education Type", "Mother's Educational Status", "Father's Educational Status", "Type of High School Student Graduated from", "Settlement Unit Where Most of Childhood was Spent", "Perception of Socioeconomic Status", "Number of siblings", "Hometown (as a region)", "Family Type" and "Relationship Status of the Parents", and "the main categories of sample value metaphor". In conclusion, no association was found between any of these variables and the main categories of sample value metaphors.

Celikten (2006) emphasizes that metaphors are a technique that can be used effectively in revealing perception and learning styles during students' mental development. As a result; metaphors can be used as a powerful research tool in understanding, revealing and explaining the perceptions of history students about the concept of "value".

In the light of this study, the following suggestions can be made:

- The results obtained related to the concept of value can give the lecturers in history departments a new perspective.

- Research should be conducted at different teaching levels to determine students' perception of value through metaphors and the results should be compared. 


\section{References}

Aladag, S., \& Kuzgun, M. P. (2015). The thoughts and metaphoric perceptions of primary school teacher candidates about value concept. Sakarya University Journal of Education Faculty, 29, 163-193.

Aydin, E., \& Sulak, S. E. (2015). Metaphor perception of prospective primary school teachers for "value" concept. Bartin University Journal of Faculty of Education, 4(2), 482-500. https://doi.org/10.14686/buefad.v4i2.5000148420

Aydin, F. (2010). Secondary school students' metaphors about the geography concept. Educational Sciences: Theory \& Practice, 10(3), 1293-1322.

Aydin, M. (2003). Youth's values perception: Konya sample. Journal of Values Education, 1(3), 121-144.

Candan, A. S., \& Aydin, F. (2016). Department of history last grade students' metaphors about the geography concept. 4th International Symposioum on History Education September 1-3, 2016. Conference Proceedings. Mugla Sitki Kocman University, 495-507.

Celikten, M. (2006). Culture and teacher metaphors. Erciyes University Journal of the Institute of Social Sciences, 1(21), 269-283.

Demir, A. T., \& Firat, D. S. (2018). Metaphors used by prospective teachers regarding the concept of value. Journal of Mother Tongue Education, 6(4), 894-923. https://doi.org/10.16916/aded.427142

Dilmac, B., Bozgeyikli, H., \& Cikili, Y. (2008). The investigation of teacher candidates' value perceptions in terms of various variables. Journal of Values Education, 6(16), 69-91.

Doganay, A. (2006). Values education. In C. Ozturk (Ed.), Life sciences and social studies education (pp. 255-286). Ankara: PegemA.

Gungor, E. (1993). Values Psychology. Amsterdam: Stichting Nederlands-Turks Academisch Genootschap.

Kilcan, B. (2013). Examining students' perceptions on values in social science teaching program. Unpublished doctoral thesis, Gazi University Institute of Educational Sciences, Ankara.

Kilcan, B., \& Akbaba, B. (2018). An investigation of student perceptions of the solidarity value in the social studies curriculum. The Journal of Turkish Social Research, 22(1), 185-210.

Lakoff, G., \& Johnson, M. (1980). Metaphors we live by. Chicago and London: University of Chicago Press.

Levine, P. M. (2005). Metaphors and images of classrooms. Kappa Delta Pi Record, 41(4), 172-175. https://doi.org/10.1080/00228958.2005.10532066

Miles, M. B., \& Huberman, A. M. (1994). Qualitative data analysis: An expanded sourcebook. Thousand Oaks, CA: Sage Publications.

Morgan, G. (1998). Metaphor in management and organization theories. İstanbul: MESS.

Perry, C., \& Cooper, M. (2001) Metaphors are good mirrors: Reflecting on change for teacher educators. Reflective Practice, 2(1), 41-52. https://doi.org/10.1080/14623940120035514

Rokeach, M. (1973). The nature of human values. New York: The Free Press.

Saban, A. (2004). Entry level prospective classroom teachers' metaphors about the concept of "teacher". The Journal of Turkish Educational Sciences, 2(2), 131-155.

Saban, A. (2009). Prospective teachers' mental images about the concept of student. The Journal of Turkish Educational Sciences, 7(2), 281-326.

Saban, A., Kocbeker, B. N., \& Saban, A. (2006). An investigation of the concept of teacher among prospective teachers through metaphor analysis. Educational Sciences: Theory \& Practice, 6(2), 509-522.

Shuell, T. J. (1990). Teaching and learning as problem solving. Theory Into Practice, 29(2), $102-108$. https://doi.org/10.1080/00405849009543439

TUBA. (2011). Turkish Science Terms Dictionary: Social Sciences, Ankara: TUBA.

Turkish Language Association. (1988). Turkish dictionary, Ankara: TDK.

Ulusoy, K., \& Dilmac, B. (2016). Values education. Ankara: Pegem Academy.

Veugelers, W. (2000). Different ways of teaching values. Educational Review, 52(1), 37-46, https://doi.org/10.1080/00131910097397 
Yildirim, A., \& Simsek, H. (2008). Qualitative research methods in social sciences. Ankara: Seckin Publishing.

Yob, I. M. (2003). Thinking constructively with metaphors. Studies in Philosophy and Education, 22, $127-138$. https://doi.org/10.1023/A:1022289113443

\section{Copyrights}

Copyright for this article is retained by the author(s), with first publication rights granted to the journal.

This is an open-access article distributed under the terms and conditions of the Creative Commons Attribution license which permits unrestricted use, distribution, and reproduction in any medium, provided the original work is properly cited. 